\title{
PASAR SEBAGAI RUANG SEDULURAN MASYARAKAT JAWA
}

\author{
Endy Marlina* \\ Arya Ronald* \\ Sudaryono** \\ Atyanto Dharoko**
}

\begin{abstract}
This study found the concept of "market as seduluran (brotherhood) space", Javanese local wisdom in managing social interactions. The concept of social harmony is the realization of Javanese local wisdom that has existed and still running today. In-depth exploration reveals empirical themes that show strategies of market management. This strategy illustrates the public perception of the market, they are market as a common space, space of dhasaran, familial spaces, social media expansion, socioeconomic space, space of paseduluran (brotherhood), chatrooms and entertainment space, changes of the management of market space, the openness of market space, and network of information, knowledge, and culture. Another finding is the task of the market as physical control, functional frame, social milieu, and cultural symbolization. The themes which were found then were further explored with eiditic depth and managed to find a concept of seduluran as the basis of public understanding of the market. The concept of seduluran underlying strategies to maintain social harmony of the society. This concept managed to keep the existence of markets as traditional economic space in the development of a modern economy.
\end{abstract}

Keywords: brotherhood, culture, space arrangement, space perception

\begin{abstract}
ABSTRAK
Studi ini menemukan konsep "pasar sebagai ruang seduluran", budaya masyarakat Jawa dalam mengelola interaksi sosial kemasyarakatan. Konsep pengelolaan interaksi ini merupakan realisasi budaya masyarakat Jawa yang telah ada dan terus berkembang hingga saat ini. Eksplorasi yang mendalam mengungkapkan tema-tema empiris yang menunjukkan strategi pengelolaan pasar. Strategi ini menggambarkan persepsi masyarakat terhadap pasar, yaitu sebagai ruang umum, ruang dhasaran, ruang kekeluargaan, media perluasan sosial, ruang sosioekonomi, ruang paseduluran, ruang perbincangan dan ruang hiburan, perubahan pengelolan ruang pasar, keterbukaan ruang pasar, dan jaringan informasi, pengetahuan, dan budaya. Temuan lain adalah peran pasar, yaitu sebagai pengontrol fisik, wadah fungsi komersial, lingkungan sosial, dan realisasi budaya. Tema-tema empiris yang ditemukan kemudian dieksplorasi dengan kedalaman eidetik dan berhasil menemukan konsep seduluran yang merupakan pemahaman masyarakat terhadap pasar. Konsep ini merupakan dasar pemikiran dalam mengembangkan strategi untuk menjaga harmoni sosial dalam bermasyarakat. Konsep ini berhasil menjaga eksistensi pasar sebagai ruang ekonomi tradisional di tengah dinamika modernisasi kegiatan ekonomi dewasa ini.
\end{abstract}

Kata Kunci: bakulan, budaya, pengelolaan ruang, persepsi ruang, seduluran

\footnotetext{
* Program Studi Arsitektur, Fakultas Sains dan Teknologi, Universitas Teknologi Yogyakarta

** Jurusan Teknik Arsitektur dan Perencanaan, Fakultas Teknik, Universitas Gadjah Mada, Yogyakarta
} 


\section{PENGANTAR}

Ruang merupakan penunjang relasi aktivitas yang dilakukan oleh suatu komunitas (Lefebvre, 1991). Aktivitas ekonomi masyarakat membutuhkan ruang untuk menopang fungsi-fungsi yang dilakukan di dalamnya. Perkembangan ruang merupakan manifestasi dari perkembangan budaya masyarakatnya. Perkembangan budaya ini akan berdampak pada berbagai hal, di antaranya adalah persepsi keruangan serta perilaku penggunaan ruang tersebut. Tumbuh dan berkembangnya pasar merupakan salah satu wujud fisik manifestasi teritori ruang oleh seseorang atau kelompok tertentu untuk menampung aktivitas ekonomi sebagai salah satu sektor penting penunjang keberlanjutan kehidupan masyarakat.

Kabupaten Bantul terletak di Provinsi Daerah Istimewa Yogyakarta, Indonesia. Kabupaten Bantul terdiri atas 17 Kecamatan yang dibagi lagi menjadi 75 (tujuh puluh lima) desa dan 933 dusun. Pusat pemerintahannya berada di Kecamatan Bantul, sekitar $11 \mathrm{~km}$ sebelah selatan Kota Yogyakarta. Masyarakat Bantul adalah masyarakat berlatar budaya Jawa.

Pemerintahan di Kabupaten Bantul dikelola dengan sistem kerakyatan. Demikian juga sistem perekonomiannya dikelola dengan sistem ekonomi kerakyatan. Sebagian besar transaksi ekonomi dilakukan secara tradisional, dengan wadah kegiatan ekonominya berupa pasar tradisional.

Pasar merupakan suatu bentuk ruang ekonomi yang dapat menggambarkan dinamika kegiatan ekonomi. Kenyataan bahwa hingga saat ini keberadaan pasar sebagai ruang ekonomi di Kabupaten Bantul masih bertahan di tengah dinamika pertumbuhan berbagai ruang ekonomi yang lebih modern merupakan satu fenomena menarik. Bahkan, pasar tetap eksis mewadahi kegiatan ekonomi masyarakat di Kabupaten Bantul setelah bencana gempa yang melanda DIY pada bulan Mei 2006.

Masyarakat ekonomi lemah merupakan masyarakat dengan kerentanan sosial-ekonomi terbesar. Namun, dalam kasus bencana tersebut, kebangkitan kegiatan ekonomi masyarakat di Kabupaten Bantul terjadi relatif cepat yang ditandai dengan pemanfaatan ruang-ruang di pasar. Fenomena-fenomena ini menjadi dasar munculnya pertanyaan: seperti apakah persepsi pengguna terhadap ruang pasar di Kabupaten Bantul? Bagaimana peran pasar bagi masyarakat di Kabupaten Bantul? Jawaban pertanyaan ini akan mengungkapkan sistem nilai masyarakat lokal yang mempengaruhi persepsi masyarakat terhadap ruang ekonomi rakyat dan pemanfaatan ruang tersebut.

Bagi pengembangan ilmu pengetahuan, tulisan ini dapat memperkaya khazanah ilmu pengetahuan, khususnya pada bidang ilmu arsitektur dan keruangan. Temuan baru tentang "ruang" merupakan perluasan khasanah pengetahuan tentang aspek "ruang" secara umum, khususnya pemahaman ruang secara spesifik yang dipengaruhi oleh latar budaya pada masyarakat. Bagi pengembangan praktik, tulisan ini dapat memberikan kontribusi positif bagi arsitek dan perencana ruang kota dalam mengevaluasi rancangan penataan ruang kota, khususnya yang terkait dengan ruang bagi sektor ekonomi. Simpulan tulisan ini dapat menjadi masukan dalam proses perencanaan dan perancangan ruang yang tanggap terhadap aspirasi masyarakat bawah. Hal ini sesuai dengan pergeseran konsepsi penataan ruang di Indonesia dewasa ini yang lebih menekankan pendekatan bottom up, menggunakan aspirasi masyarakat pengguna ruang sebagai satu komponen penting yang harus dipertimbangkan. Tulisan ini juga dapat memberikan manfaat bagi pemerintah, yaitu sebagai rujukan dalam mengevaluasi dan menyusun rencana ruang secara umum.

Persepsi adalah proses aktif yang dilakukan oleh seseorang dalam menilai lingkungan/ruang di sekitarnya. Proses ini melibatkan kelima indera manusia (Lawson, 2001). Persepsi lingkungan (environmental perception) adalah interpretasi tentang suatu seting oleh individu yang didasarkan pada latar belakang budaya, nalar, dan pengalaman individu tersebut (Haryadi, 1995). Masing-masing individu mempunyai persepsi lingkungan yang 
berbeda karena latar belakang budaya, nalar serta pengalaman yang berbeda.

Ruang diciptakan untuk mengakomodasi aktivitas manusia sehingga perlu didesain dan dilengkapi dengan sarana penunjang sesuai dengan maksud pembangunannya. Pengertian ruang meliputi bentuk fisik serta aktivitas manusia di dalamnya (Habraken, 1998). Setelah diciptakan dan selama proses pemanfaatannya, ruang tumbuh dan berkembang bersama dengan manusia yang menghuninya (Habraken, 1998). Aktivitas inilah yang kemudian memberi nafas, makna, dan nilai pada ruang tersebut. Hal ini juga dikuatkan oleh Norberg Schulz bahwa pengertian ruang dapat mencakup aspek psikologis maupun aspek fisik (Schulz, 1977). Dalam hubungannya dengan ruang, manusia adalah agen perubah yang mempunyai kuasa mengatur dan mengendalikan ruang sesuai dengan keinginannya (Habraken, 1998).

Hubungan antara ruang dan penghuninya (manusia) merupakan rekaman dari perjalanan hidup manusia yang apabila ditelusuri dapat memberikan gambaran perilaku manusia serta perubahannya selama kurun waktu penghunian ruang tersebut (Marlina, 2011). Ruang dapat dipahami sebagai implementasi dari kehidupan manusia yang meliputi beberapa aspek, yaitu (1) ruang sebagai tatanan fisik, (2) ruang sebagai tatanan teritori, dan (3) ruang sebagai tatanan budaya (Habraken, 1998). Sebagai wadah kegiatan manusia, ruang dapat mempunyai empat peranan, yaitu (1) physical control, (2) functional frame, (3) social milieu, dan (4) cultural symbolization (Schulz, 1977). Berdasar kepemilikannya, ruang dapat dibagi dalam ruang privat, ruang semipublik, dan ruang publik (Moundon, 1987).

Konsep mengenai ruang (space) selama ini dikembangkan melalui beberapa pendekatan yang berbeda dan selalu mengalami perkembangan. Setidak-tidaknya terdapat tiga pendekatan yang selama ini mendominasi literaturliteratur mengenai pemanfaatan ruang, yaitu (1) pendekatan ekologis (ecological approach), (2) pendekatan ekonomi dan fungsional (functional/ economical approach), dan (3) pendekatan sosialpolitik (socio-political approach) (Friedman dan Weaver, 1979; Harvey, 1973). Pengendalian ruang oleh suatu kelompok menjadi sangat penting. Dalam pandangan ini, aspek equity (distribusi) ruang menjadi persoalan penting.

Setiap manusia mempunyai cara berbeda untuk membahasakan ruang. Cara ini dapat mencakup cara merasakan ruang dan cara bergerak dalam ruang. Oleh karena itu, untuk mencapai nilai tertentu, ruang perlu diatur dan dikendalikan sesuai dengan motivasi dan kebutuhan penghuniannya. Nilai ruang adalah nilai yang menggambarkan hubungan yang kongruen antara aktivitas manusia, tatanan fisik ruang, dan tatanan sosial (Lawson, 2001).

Pada proses sosial, perilaku interpersonal manusia meliputi hal-hal penting yang berkaitan dengan ruang personal (personal space), teritorialitas, kesesakan dan kepadatan serta privasi. Menurut Altman, teritori adalah cara mengatur batas individu, termasuk personalisasi atau penandaan suatu daerah/objek sebagai miliknya (Altman, 1975). Personalisasi dan kepemilikan di sini dirancang untuk mengatur interaksi sosial. Pendapat yang sama juga diungkapkan oleh Sommer bahwa teritori merupakan cara mengontrol area oleh individu, keluarga, atau grup (Sommer, 1966). Area teritori ini ditandai dengan suatu cara dan dipertahankan dari pelanggaran. Teritori juga merupakan salah satu cara untuk mengatur penerimaan terhadap tingkat privasi yang diharapkan (Goffman, 1963). Teritorialitas ruang menggambarkan adanya kontrol pada ruang tersebut (Habraken, 1998).

Privasi merupakan proses pengaturan dari seseorang atau sekelompok orang untuk diterima atau menerima orang lain (Altman, 1975). Dalam konsep privasi ini terkandung kemampuan untuk mengontrol, memilih, merencanakan, dan mengatur interaksi yang tidak diharapkan serta mencapai interaksi yang diinginkan (Rapoport, 1972; Westin, 1970; Proshansky, 1970). Kesesakan berhubungan erat dengan tingkat privasi yang diinginkan. Apabila privasi 
yang diterima jauh lebih kecil dari privasi yang diinginkan, akan timbul kesesakan. Sebaliknya, apabila privasi yang diterima lebih besar dari yang diinginkan, akan menimbulkan kesepian (Altman, 1975). Ruang personal merupakan area di sekeliling individu yang dipelihara dari individu lainnya (Hediger, 1950). Ruang personal ini diperlukan oleh setiap individu untuk mendapatkan kenyamanan dalam berinteraksi dengan individu lain (Sommer, 1969).

Lingkup spasial studi ini adalah Kabupaten Bantul, DIY. Lingkup substansial terkait dengan persepsi masyarakat terhadap ruang pasar dan implementasi persepsi tersebut dalam pemanfaatan ruang-ruang yang didekati melalui disiplin ilmu arsitektur. Fokus studi adalah persepsi masyarakat terhadap ruang yang meliputi aspek rasa terhadap ruang (melibatkan lima indera), pengaruh ruang terhadap pengguna, dan respons pengguna terhadap ruang tersebut. Aspek-aspek yang diamati adalah penggunaan ruang pasar yang terkait dengan sejumlah komponen yang melekat (waktu penggunaan, jenis penggunaan, karakteristik pemakai, dan lokasi spesifik penggunaan).

\section{Gambar 1}

Siklus Penggalian Data, Analisis, dan Penarikan Temuan Sementara

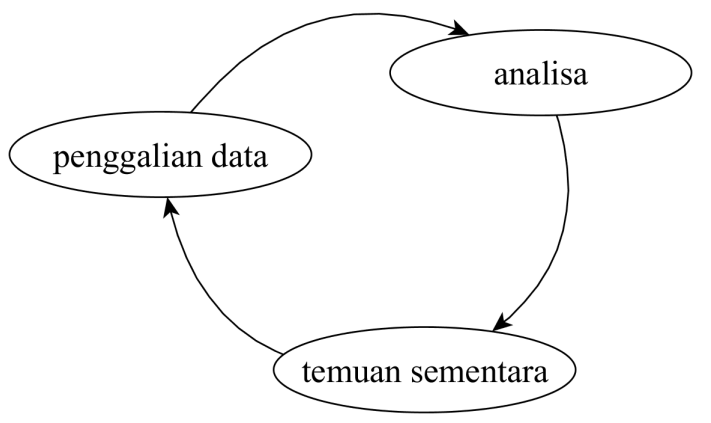

Penggalian informasi dilakukan melalui wawancara dengan pengguna ruang sebagai narasumber. Penggalian data dilakukan dengan cara purposive sampling (Moloeng, 1983). Instrumen pengumpul data pada studi ini adalah peneliti sendiri, untuk menggali informasi dan menangkap realitas ganda (Muhajir, 1990).
Dengan interaksi timbal balik ini, setiap data yang terkumpul dapat dikonfirmasikan dengan dan antarresponden sehingga mencapai hasil dengan validitas yang lebih baik (Muhajir, 1990).

\section{Gambar 2}

\section{Gambaran Reduksi Fenomenologis dalam Menggali Informasi mengenai Fenomena Ruang Pasar}

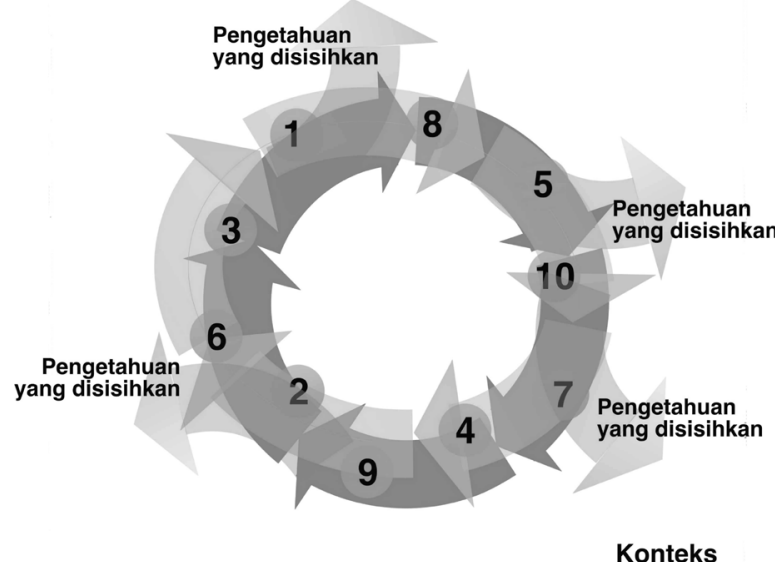

Studi dilakukan secara kualitatif dengan pendekatan fenomenologis dan menggunakan analisis data secara induktif. Wawancara dilakukan secara fleksibel sehingga memungkinkan penggalian informasi spesifik dari setiap sampel. Hasil wawancara merupakan temuan sementara yang digunakan sebagai pengetahuan latar dalam wawancara berikutnya, seperti digambarkan dalam Gambar 1. Hasil ini dihargai berdasarkan spesifikasinya dan tidak digunakan sebagai kerangka penyeragaman pada tahap wawancara berikutnya. Namun demikian, temuan dari setiap sampel tetap diperiksa ulang pada sampel yang lain.

Studi mengenai tatanan ruang pasar ini dilakukan dalam 2 tahap reduksi, yaitu reduksi fenomenologis dan reduksi eiditik. Pada tahap awal studi ini, fenomena ruang pasar digali berdasarkan realita dan informasi lapangan. Sesuai dengan tahap reduksi fenomenologis, pengetahuan dan informasi yang dimiliki sebelumnya sementara disisihkan agar tidak mencemari fenomena ruang pasar pasca gempa yang dibangun oleh masyarakat pasar. Proses reduksi fenomenologis itu dapat dilihat pada Gambar 2. 
Proses analisis dilakukan dari awal sejak dilakukannya observasi awal dalam rangka menemukan sampel. Analisis terus berjalan seiring dengan jalannya penggalian data dan pengkerangkaan temuan-temuan. Proses ini juga dilengkapi dengan penarikan simpulan-simpulan sementara yang secara berulang dikaji pada proses penggalian data dan analisis berikutnya. Secara geometris proses studi ini dapat digambarkan berupa siklus yang selalu berputar antara penggalian data, analisis, dan penarikan simpulan yang berulang hingga didapatkan simpulan akhir (temuan final) pada saat perulangan temuan tidak melahirkan lagi simpulan baru.

Studi ini dilakukan dalam dua tahap reduksi, yaitu reduksi fenomenologis dan reduksi eiditik. Pada tahap awal, fenomena ruang pasar digali berdasarkan realita dan informasi lapangan. Observasi secara intensif dilakukan untuk menggali informasi mengenai ruang pasar apa adanya sesuai dengan yang ditampilkan oleh masyarakat pasar kontekstual dengan lingkungan pasar. Informasi ruang pasar berdasarkan realita lapangan adalah (a) dapat didatangi, digunakan, diatur oleh semua orang, (b) berkaitan dengan cara menampilkan (ndhasarke) barang dagangan, (c) menunjukkan peranan pasar terhadap pengasuhan keluarga, (d) menunjukkan peranan pasar dalam memperluas relasi sosial, (e) menunjukkan dominasi aspek sosial dalam kegiatan ekonomi, (f) menunjukkan dominasi aspek sosial dalam kegiatan ekonomi, (g) menunjukkan peranan pasar dalam mengembangkan persaudaraan (seduluran), (h) menunjukkan pemanfaatan pasar untuk saling bertemu dan mendapatkan kesenangan, (i) menggambarkan adanya perubahan dalam pengelolaan ruang pasar, (j) menggambarkan pasar sebagai ruang yang terbuka untuk mengakomodasi berbagai peluang, (k) menunjukkan peranan pasar dalam menyebarkan informasi, pengetahuan, dan budaya masyarakat.

Informasi yang berhasil digali melalui reduksi fenomenolgis ini kemudian dikonstruksi secara induktif dan menghasilkan temuan sebagai berikut.

\section{PERKEMBANGAN PASAR DALAM MASYARAKAT JAWA}

Di lokasi studi, masyarakat menyebut kegiatan jual beli sebagai kegiatan bakulan, yaitu kegiatan tukar menukar/transaksi yang dilakukan dalam suasana kemasyarakatan/sosial. Pengertian bakulan mencakup kegiatan yang mempunyai nilai ekonomi sekaligus nilai sosial. Pelaku kegiatan bakulan mencakup penjual (bakul) dan pembeli (wong tuku). Dengan demikian, pengertian "pasar" bagi masyarakat di lokasi studi adalah tempat terjalinnya hubungan dan keteranyaman antara bakul, wong tuku, dan kegiatan bakulan. Dalam pengertian ini, pasar berperan mewadahi kegiatan jual beli sekaligus interaksi sosial masyarakat. Dengan merujuk pada Schulz (1977), berarti pasar berperan mewadahi fungsi komersial sekaligus dalam pengembangan nilai sosial.

Pada awalnya, pasar berasal dari beberapa kegiatan bakulan yang tumbuh dan berkembang di suatu area di desa. Seiring dengan berjalannya waktu, masyarakat yang beraktivitas jual beli di area itu semakin banyak. Operasional pasar dilakukan berdasarkan kesepakatan-kesepakatan di antara para pelakunya. Perkembangan kegiatan pasar didukung dan difasilitasi oleh pengelola desa. Pasar makin lama menjadi semakin besar. Kemudian, pemerintah berkoordinasi dengan pemerintah setempat memfasilitasi kegiatan itu, dengan membangunkan ruang bakulan sederhana yang bisa disewa oleh masyarakat. Pemerintah juga memfasilitasi pengelolaan pasar dengan mengadakan petugas pengelola pasar yang membantu pengelolaan administrasi ruang pasar. Pada awalnya, ruang-ruang bakulan yang dibangun berupa ruang semi terbuka yang dilengkapi dengan atap sebagai pelindung kegiatan dan lantai tetapi tanpa dinding. Selama masa penggunaan ruang-ruang bakulan itu, masyarakat secara bertahap melakukan berbagai penyesuaian pada ruang bakulan itu sesuai dengan kebutuhannya masing-masing. Artinya, masyarakat mengendalikan ruang itu. 


\section{PENGADAAN RUANG BAKULAN DI PASAR}

Berdasarkan cara pengadaannya, ruang bakulan dapat dibedakan sebagai ruang bakulan siap pakai dan ruang bakulan swadaya. Ruang bakulan siap pakai adalah ruang bakulan yang disediakan oleh pemerintah, disewa, atau dikatakan "dibeli" (dibeli hak pakainya) oleh masyarakat. Termasuk dalam kelompok ini adalah kios dan los.

Ruang bakulan swadaya adalah ruang yang dibangun oleh bakul, baik perseorangan maupun bersama-sama. Meskipun pemerintah melakukan campur tangan dalam pembangunan dan pengelolaan pasar, namun masih terdapat keleluasaan bagi masyarakat untuk mengembangkan pasar tersebut. Masih terdapat cukup area kosong di pasar untuk mengakomodasi aspirasi masyarakat. Pada area-area inilah, masyarakat berpeluang untuk membangun ruang bakulan sesuai dengan kebutuhannya. Ruang bakulan swadaya ada yang bersifat permanen dan ada juga yang bersifat temporer (sementara). Ruang bakulan swadaya yang bersifat permanen adalah bango, sedangkan ruang bakulan swadaya yang bersifat temporer disebut adaan. Pembangunan bango ada yang dilakukan secara gotong-royong dan ada juga yang dibangunkan oleh tukang, sedangkan pembangunan adaan biasanya dilakukan sendiri oleh $\mathrm{Si}$ Bakul. Pembangunan bango dilakukan oleh sekelompok masyarakat, berkoordinasi dengan pengelola pasar. Wakil dari kelompok masyarakat ini berembug dengan pengelola pasar dalam menentukan tempat yang dapat digunakan untuk pembangunan bango, tata tertib, dan iuran sewa lahan yang harus dibayar oleh bakul-bakul pengguna bango.

Masyarakat membangun bango secara swadaya untuk mewadahi kegiatan bakulan mereka. Pembangunan bango juga dilakukan secara gotong-royong oleh masyarakat. Oleh karena itu, penampilan bango sangat dipengaruhi oleh kemampuan dan kelonggaran keuangan para pengguna bango itu.

Bagi masyarakat pasar, bergotong-royong seperti ini merupakan hal yang biasa mereka lakukan. Kebiasaan ini adalah cara mereka memelihara kedekatan hubungan antara satu orang dengan lainnya. Gotong-royong juga membuat para bakul merasa saling membutuhkan satu dengan lainnya, dan pekerjaan-pekerjaan yang berat akan menjadi terasa lebih ringan. Dalam hal ini, tergambarkan bahwa pasar mempunyai peranan sebagai wadah dan generator berkembangnya nilai sosial, terutama nilai persaudaraan. Terwujudnya bangunan-bangunan di pasar, dalam hal ini merupakan realisasi budaya masyarakat Jawa yang menjunjung tinggi kerukunan dan paseduluran.

\section{TATANAN RUANG BAKULAN DI PASAR}

Secara umum, ruang bakulan di pasar dapat dikelompokkan menjadi ruang tertutup dan ruang semi terbuka. Ruang bakulan tertutup adalah ruang bakulan dengan pembatas pada bagian atas (atap), bawah (lantai), dan samping (dinding), berupa warung dan kios. Ruang bakulan semi terbuka adalah ruang bakulan yang hanya memiliki pembatas di bagian atas (atap) dan bawah (dinding), berupa los, bango, dan adaan. Los berupa bangunan semi terbuka panjang dilengkapi dengan lantai dan atap bangunan. Bango adalah bangunan dengan bentuk serupa los, tetapi materialnya lebih sederhana. Adaan adalah ruang bakulan dengan bentuk sangat sederhana sehingga berkesan seperti ruang bakulan darurat. Menurut para bakul, justru dengan tidak membatasi ruang bakulan mereka bisa lebih mudah saling berkomunikasi dan dapat merasakan kesan ruang yang lebih luas. Tatanan ini membuat wong tuku sering juga meluangkan waktu untuk berlama-lama berbincang dengan bakul-bakul dan pengguna pasar yang lain.

Berdasarkan susunannya, ruang bakulan dapat dikelompokkan menjadi tatanan ruang bakulan berderet dan berkelompok. Tatanan ruang bakulan berderet contohnya los, kios, atau bango. Deretan kios biasanya terletak di tepi pasar sehingga sekaligus menjadi pembatas area pasar. Los 
biasanya terletak di area tengah pasar, berderetderet dengan pola grid dan terdapat jalur sirkulasi di antara los satu dengan lainnya.

Pada sebagian pasar, masih terdapat area-area kosong yang dapat dimanfaatkan oleh masyarakat untuk membangun ruang bakulan satuan seperti adaan, warung, bango, dan berbagai fasilitas pasar yang diperlukan, misalnya parkir kendaraan. Pada waktu-waktu tertentu kegiatan di pasar menggembung dan melibatkan lebih banyak bakul dan wong tuku, yaitu pada hari pasaran/pekenan. Saat itu area-area kosong di pasar dimanfaatkan masyarakat untuk melakukan bakulan. Para bakul pekenan ini biasanya membangun adaan. Bakulbakul musiman itu membangun ruang bakulan non permanen secara berkelompok di tempat-tempat tertentu.

Menurut para bakul, mereka mengelompok satu dengan lainnya agar mempunyai tetangga bakul dan mempunyai teman bicara selama berkegiatan di pasar. Seorang bakul juga membutuhkan orang lain. Misalnya suatu ketika seorang bakul merasa lelah dan memerlukan istirahat, atau perlu ke kamar mandi. Dagangan yang ditinggalkan tentunya perlu dititipkan pada bakul lain. Apabila ada wong tuku pada saat itu, tetangga bakulnya akan menolong menyelesaikan bakulan itu.

Tatanan fisik ruang bakulan disusun sesuai aspirasi penggunanya, dalam hal ini bakul, dengan mempertimbangkan beberapa hal, yang paling dominan adalah kemudahan dalam melayani wong tuku. Pengertian "melayani" ini mencakup layanan ekonomi (bakulan) dan layanan lain yang mendukung kegiatan ekonomi.

Fenomena di atas menunjukkan bahwa pasar dikembangkan untuk mewadahi fungsi jual beli. Untuk mengakomodasi kegiatan itu, ruang di pasar ditata sesuai dengan kontrol ruang yang diinginkan. Menurut Schulz (1977), artinya pasar mempunyai peranan sebagai kontrol fisik dan wadah suatu fungsi. Selain itu, pasar juga ditata untuk mengembangkan interaksi sosial antara penggunanya (Schulz, 1977). Merujuk pada Lawson (2001), Habraken (1998), dan
Haryadi (1995) tatanan pasar merupakan realisasi pemahaman pengguna terhadap ruang, yang berkembang secara spesifik didasari oleh budaya mereka.

\section{KONTROL RUANG BAKULAN DI PASAR}

Kegiatan yang berkembang di ruang bakulan membentuk pola yang secara keruangan dapat menunjukkan tingkat pengendalian/kontrol ruang. Ruang bakulan secara umum mewadahi dua area, yaitu area bakul (area gerak bakul) dan area wong tuku (area gerak wong tuku). Tingkat pengendalian/kontrol ruang bakulan dapat dikelompokkan menjadi tiga kelompok berikut (Marlina, 2014).

1. Kontrol ruang longgar (Gambar 3), yaitu pengendalian/kontrol ruang yang memungkinkan terjadinya interaksi spasial antara bakul dan wong tuku secara bebas. Dalam hal ini, kontrol terhadap area bakul relatif longgar untuk menerima intervensi wong tuku. Ruang bakulan ditata secara terbuka di bagian depan. Penataan ruang semacam ini memberikan peluang bagi wong tuku untuk masuk ke dalam ruang bakulan dan memilih langsung barang-barang yang akan dibelinya, juga memungkinkan terjadinya jarak yang lebih dekat antara bakul dan wong tuku sehingga percakapan dapat terjadi secara lebih intensif.

2. Kontrol ruang setengah longgar (Gambar 3), yaitu pengendalian/kontrol ruang yang memungkinkan terjadinya interaksi spasial antara bakul dan wong tuku dengan batasan tertentu, misalnya untuk wong tuku tertentu atau untuk jangkauan tertentu. Penataan ruang bakulan dilakukan dengan membuat sedikit pembatas antara ruang gerak bakul dan ruang gerak wong tuku, tetapi tidak sampai menutup akses ke dalam area bakul.

3. Kontrol ruang sakleg (Gambar 3), yaitu pengendalian/kontrol ruang yang tidak memungkinkan terjadinya interaksi spasial antara bakul dan wong tuku. Ruang bakulan ditata dengan menempatkan barang-barang 
atau perlengkapan di sisi depan area bakulan sehingga menutup akses dari area wong tuku ke area bakul. Dalam hal ini, pengendalian/ kontrol terhadap area bakul relatif ketat, tidak menerima intervensi gerak wong tuku. Pada tatanan seperti ini, wong tuku memahami isyarat tersebut dan tidak menuntut untuk bisa memasuki area bakul itu.

Gambar 3

Pengendalian/kontrol Ruang Bakulan di Pasar
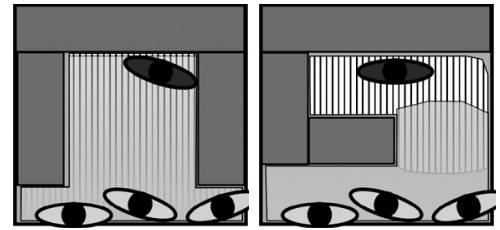

1. Kontrol ruang

2. Kontrol longgar ruang setengah longgar



3. Kontrol ruang sakleg

Keterangan:

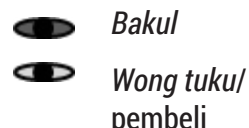

$\square$ Perlengkapan bakulan pembeli

IIII Area bakul

Area wong tuku/ pembeli

(Sumber: Observasi lapangan, Juni 2012)

Pengendalian/kontrol ruang yang dibangun oleh bakul sebagai "pengendali" ruang bakulan menunjukkan pemikiran dan aspirasi mereka. Upaya mengontrol dan membatasi peruntukan ruang bagi diri sendiri atau kelonggaran dalam memperbolehkan orang lain memasuki areanya menunjukkan aspirasi para bakul untuk mengelola tingkatan keterjangkauan ruang itu. Dalam pola peruangan ini berlaku pengertian "ruang bakul" dan "ruang wong tuku". Ruang bakul adalah ruang yang menjadi area gerak bakul, sedangkan ruang wong tuku adalah ruang yang menjadi area gerak wong tuku. Dalam persepsi ini, bakul adalah "pemilik" ruang bakulan secara keseluruhan (tuan rumah), sedangkan pembeli adalah saudara yang "mampir" (tamu) di ruang tersebut. Oleh karenanya, eksistensi ruang wong tuku mempunyai durasi yang lebih pendek. Namun demikian, bakul sangat menghargai dan menghormati keberadaan Si Tamu. Penghormatan ini ditunjukkan dengan keramahan layanan, baik bagi "tamu" yang diterima dengan sangat longgar karena hubungan yang dekat, maupun bagi "tamu" yang diterima dengan batasan karena hubungan yang belum terlalu dekat. Sesuatu yang sangat diutamakan oleh para bakul adalah penerimaan yang menyedulur (menyaudara) agar dapat membekas di hati "tamu"-nya dan membangun persaudaraan yang berumur panjang.

Observasi dan wawancara mendalam studi ini memberikan gambaran bahwa ruang bakulan di pasar dikembangkan sesuai keinginan para penggunanya untuk mendekatkan diri dan mengembangkan persaudaraan di antara mereka. Motivasi ini diimplementasikan dalam penataan ruang bakulan dengan pelonggaran kontrol ruang yang memungkinkan terjadi dan menguatnya relasi sosial di antara masyarakat pasar. Dengan merujuk pada Goffman (1963), Sommer (1966), Altman (1975), dan Habraken (1998), cara pengguna mengontrol ruang di pasar bukan sekadar didasari dengan pertimbangan ekonomi meskipun pasar merupakan ruang kegiatan ekonomi, namun aroma pertimbangan sosial justru lebih terasa. Hal ini menunjukkan pemahaman pasar sebagai media pengembangan sosial, yang artinya merupakan realisasi dari praktik budaya masyarakat.

\section{CARA BAKULAN DI PASAR}

Bakulan di pasar dilakukan sesuai dengan aspirasi pelakunya, dapat dikelompokkan menjadi: 1) bakulan lesehan, 2) bakulan lungguh (duduk), dan 3) bakulan ngadeg (berdiri). Ruang bakulan dilengkapi dengan berbagai perlengkapan yang dibutuhkan untuk mendukung kegiatan dan ditata dengan pertimbangan tertentu. Tatanan fisik ruang ini kemudian saling mempengaruhi perilaku bakul dan wong tuku ketika melakukan kegiatan bakulan, serta interaksi dan kegiatan lainnya. Penataan ruang bakulan secara lesehan yang hanya menggunakan perlengkapan sangat sedikit memberikan ruang yang lega untuk mengantisipasi penyediaan ruang bermain atau beristirahat bagi anak-anaknya yang menyusul ke pasar. Pada tatanan ruang bakulan lungguh dan bakulan ngadeg, peralatan yang digunakan 
lebih banyak dibandingkan dengan tatanan ruang bakulan lesehan. Jangkauan Si Bakul pada barang-barang dagangan di sekelilingnya semakin jauh pada bakulan lungguh dan bakulan ngadeg sehingga fleksibilitas gerak bakul lebih banyak dibandingkan pada bakulan lesehan.

Pengembangan ruang bakulan di pasar dipengaruhi oleh keinginan bakul untuk memberikan peluang berkumpul bagi anak atau anggota keluarga yang lain pada saat melakukan kegiatan bakulan. Penataan ruang bakulan ini juga menunjukkan pengendalian ruang yang memberikan peluang bagi berkembangnya relasi sosial antara bakul dengan para pengguna pasar lainnya. Tatanan ruang yang sederhana dan mudah disesuaikan dipilih para bakul untuk memberikan peluang dalam mengembangkan hubungan persaudaraan dengan anggota masyarakat pasar lainnya.

Kegiatan bakulan di pasar-pasar di lokasi studi dilakukan dengan cara yang sederhana, yaitu dengan tawar-menawar. Interaksi ekonomi dalam kegiatan tawar-menawar penuh dengan suasana keakraban di antara bakul dan wong tuku. Setelah dicapai kesepakatan harga, transaksi jual beli dilakukan. Dalam hal ini pasar selain merupakan wadah kegiatan ekonomi juga merupakan media pengembangan interaksi sosial dan persaudaraan masyarakat.

\section{INTENSITAS KEGIATAN BAKULAN DI PASAR}

Kegiatan bakulan di pasar di Kabupaten Bantul dipengaruhi oleh sistem penanggalan budaya Jawa. Dalam penanggalan ini, satu siklus waktu disebut sebagai sepekan (sepasar) yang terdiri atas 5 hari (penanggalan pancawara), yaitu Kliwon, Legi, Paing, Pon, dan Wage. Pada awalnya, setiap pasar sebagai wadah kegiatan bakulan rakyat mempunyai waktu operasional khusus yaitu 1 hari dalam sepekan. Berdasarkan hari tersebut pasar-pasar itu diberi nama, misalnya Pasar Kliwon dan Pasar Legi.

Sebagian dari pasar-pasar di lokasi studi masih ada yang hanya beroperasi khusus pada hari tertentu sesuai sistem pasaran, sedangkan sebagian lainnya beroperasi setiap hari. Perubahan waktu operasional pasar ini dapat dipengaruhi oleh berbagai hal, di antaranya adalah lokasi pasar yang strategis. Salah satu contohnya adalah Pasar Ngangkruk yang berlokasi di tepi jalan raya yang sangat ramai. Awalnya, Pasar Ngangkruk beroperasi setiap pekenan Kliwon. Pasar Ngangkruk kemudian beroperasi setiap hari karena ketika Kliwon intensitas kegiatannya melonjak secara signifikan.

Pada pasar-pasar dinan, intensitas kegiatan bakulan yang terjadi mempunyai fluktuasi yang berbeda. Pada hari pasaran/pekenan intensitas kegiatan bakulannya sangat tinggi, sedangkan pada hari lain intensitasnya jauh lebih rendah. Tatanan fisik pasar sebagai ruang bakulan karenanya mengalami perubahan berdasarkan intensitas kegiatan yang terjadi. Fluktuasi kegiatan pasar ini mempengaruhi pemanfaatan ruang pasar yang menunjukkan adanya fleksibilitas pasar, menyempit dan melebar.

Pada saat pekenan, intensitas kegiatan pasar, jumlah bakul dan wong tuku yang bertransaksi meningkat secara signifikan. Pasar menjadi sangat padat, jarak ruang bakulan satu dengan ruang bakulan lainnya sangat berdekatan. Hampir semua area kosong di pasar dimanfaatkan oleh masyarakat untuk berkegiatan, baik kegiatan bakulan maupun kegiatan lainnya seperti parkir kendaraan, berbincang-bincang, dan lainnya. Banyak bakul pekenan membangun adaan untuk mewadahi kegiatan bakulannya.

Pada saat pekenan, waktu operasional pasar lebih panjang apabila dibandingkan dengan rerata waktu operasional pasar dinan. Banyaknya wong tuku atau masyarakat umum yang datang ke pasar dimanfaatkan oleh para bakul untuk memperbesar peluang mendapatkan penghasilan dari kegiatan bakulan-nya dengan cara memperpanjang waktu bakulan-nya. Sebaliknya, banyaknya bakul yang berkegiatan di pasar pada saat pekenan juga dimanfaatkan oleh wong tuku dan masyarakat umum untuk mencari berbagai barang yang dibutuhkan. 
Pekenan menjadi peristiwa ekonomi sekaligus peristiwa sosial budaya bagi masyarakat. Selain mewadahi kegiatan ekonomi dengan intensitas yang besar, pekenan juga dijadikan event untuk memperkuat interaksi sosial lama dan mengembangkan interaksi sosial baru. Pekenan juga menjadi media pertukaran budaya antara masyarakat, bahkan dari tempat-tempat yang sangat berjauhan. Dengan merujuk pada Habraken (1998), peranan pasar yang terbentuk saat ini merupakan realisasi perkembangan budaya masyarakat sejak dulu. Aktivitas yang berkembang di pasar ini memberikan nafas, makna, dan nilai pada ruang pasar. Hal ini sesuai dengan pernyataan Norberg Schulz, bahwa pengertian ruang dapat mencakup aspek psikologis maupun aspek fisik (Schulz, 1977).

\section{DURASI KEGIATAN BAKULAN}

Para bakul mempunyai kebebasan untuk menentukan waktu kegiatannya. Namun demikian, dalam kebebasan yang ada, tetap berlaku "aturan" yang tumbuh dan berkembang berdasarkan kebiasaan dan kesepakatan-kesepakatan yang bersumber dari norma sosial masyarakat setempat yang harus dipenuhi untuk menghindarkan terjadinya konflik penggunaan ruang di pasar. Kebebasan menentukan waktu kegiatan ini menghasilkan durasi bakul melakukan kegiatan bakulan di pasar di lokasi studi, yaitu bakulan krempyeng, bakulan mbedug, dan bakulan dinan. Bakulan krempyeng adalah bakulan yang dilakukan dalam waktu sebentar (sak krempyengan), kira-kira selama sekitar $1 / 4$ hari (dari jam buka pasar/jam 4 atau 5 pagi sampai jam 10-an); bakulan mbedug adalah bakulan yang dilakukan selama sekitar $1 / 2$ hari (dari jam buka pasar/jam 4 atau 5 pagi sampai tengah hari/waktu salat zuhur, disebut demikian karena saat salat zuhur biasanya ditandai dengan azan dan bunyi bedug); dan bakulan dinan adalah bakulan yang dilakukan dari pagi hingga sore hari (dari jam buka pasar/jam 4 atau 5 pagi sampai jam 5 sore).

Berdasarkan observasi, bakul krempyeng biasanya dilakukan oleh para bakul dinan yang melakukan kegiatan bakulan setiap hari, tidak tergantung hari pasaran. Kebanyakan mereka menjual bahan-bahan kebutuhan sehari-hari seperti sayur-mayur, bumbu, dan lauk-pauk yang harus berada dalam kondisi segar. Oleh karena itu, jumlah dagangan mereka umumnya tidak terlalu banyak sehingga akan habis dalam waktu relatif singkat. Hal ini karena bahan-bahan itu paling baik dijual dalam kondisi segar. Apabila disimpan terlalu lama, bahan-bahan tersebut akan layu dan kurang menarik untuk ditawarkan.

Bakul mbedug dan bakul dinan biasanya dilakukan oleh bakul yang menjual barang-barang nonmakanan, atau bahan mentah yang awet, mempunyai umur panjang seperti beras, gula, dan bahan pokok lainnya. Bakul dinan banyak dilakukan oleh bakul pekenan, yaitu bakul yang melakukan kegiatan bakulan di suatu pasar dengan menyesuaikan hari pasaran-nya.

Pada hari pasaran, jumlah bakul dan wong tuku di suatu pasar sangat banyak dan waktu aktif pasar lebih panjang. Banyak bakul dan wong tuku serta masyarakat yang khusus menyempatkan mengunjungi pasar pekenan untuk mencari/ membeli barang-barang tertentu yang tidak setiap hari dijumpai di pasar. Selain itu, tidak jarang mereka juga bertujuan untuk menjumpai orang tertentu, atau mempunyai kepentingan tertentu yang tidak selalu terkait dengan kegiatan bakulan.

\section{RAGAM KEGIATAN DI PASAR}

Eratnya kaitan antara kegiatan ekonomi dengan kegiatan lain dari masyarakat mengakibatkan terjadinya pewadahan kegiatankegiatan lain di pasar. Salah satunya adalah kegiatan kekeluargaan, seperti mengasuh anak yang dilakukan baik oleh bakul maupun wong tuku. Menurut para bakul, kegiatan bakulan adalah kegiatan yang santai, dapat dikelola sesuai kebutuhan. Santainya kegiatan bakulan membuat para bakul bisa melakukan kegiatannya sambil mengasuh anak. Pemandangan yang khas ini dimungkinkan karena pada umumnya sekolah anak-anak mereka masih di desa yang sama atau setidaknya di desa tetangga. Bakul yang masih 
mempunyai anak balita bahkan mengajak anaknya ke pasar sejak pagi saat mereka memulai kegiatan bakulan-nya. Agar kegiatan mengasuh anak dapat dilakukan dengan lebih nyaman, mereka juga menyimpan mainan, sarana-sarana yang mendukung pengasuhan anak seperti lendang gendong, jarik, perlak, dan perlengkapan lainnya di ruang bakulan-nya.

Sebagai ruang ekonomi, dominasi kegiatan sosial di pasar ternyata cukup besar. Berbagai kegiatan sosial, baik yang secara erat mendukung kegiatan ekonomi maupun yang kurang erat mendukung kegiatan ekonomi terjadi secara tumpang-tindih. Bagi masyarakat di lokasi studi, pasar bukan sekedar tempat bakulan. Banyak orang yang pergi ke pasar untuk urusan yang berbeda.

Pasar-pasar di lokasi studi merupakan pasar Kecamatan, yang melayani masyarakat desa tempat pasar tersebut berada dan masyarakat desa-desa sekitarnya yang berdekatan. Bakulbakul yang bakulan di pasar itu kebanyakan adalah masyarakat setempat, demikian juga para pembelinya. Sebagian besar di antara mereka sudah saling kenal, bahkan banyak juga yang mempunyai hubungan persaudaraan.

Kedekatan hubungan antara para pengguna pasar ini membentuk suasana khas di pasar. Antara satu bakul dengan bakul lainnya mempunyai hubungan yang sangat dekat, selain karena hampir selalu bertemu pada saat bakulan, banyak di antara mereka yang memang sudah saling kenal sebelumnya. Hal yang sama juga terjadi dengan wong tuku. Antara para bakul dan wong tuku banyak yang sudah saling kenal. Sambil bakulan, mereka selalu terlibat dalam interaksi sosial yang akrab, membentuk setting area yang khas seperti ditunjukkan dalam Gambar 4. Di sela-sela kegiatan bakulan, mereka berbincang dan bercanda. Kegiatan bakulan tidak dilakukan dengan tergesa-gesa karena kesempatan berkumpul dan berbincang itu sangat mereka nikmati.

\section{Gambar 4}

Perluasan Area Bakul dan Wong Tuku karena Implementasi Konsep Sosioekonomi
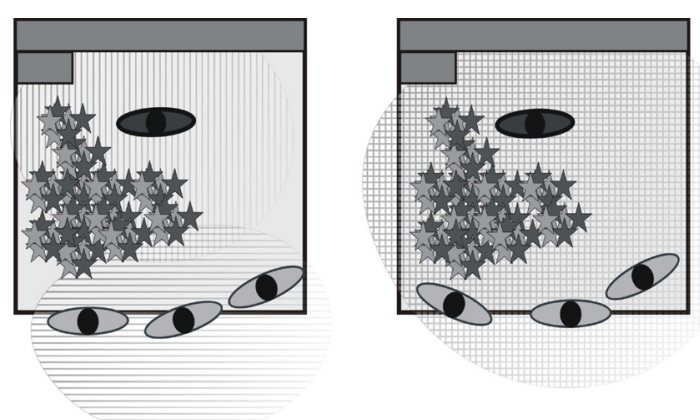

Keterangan:
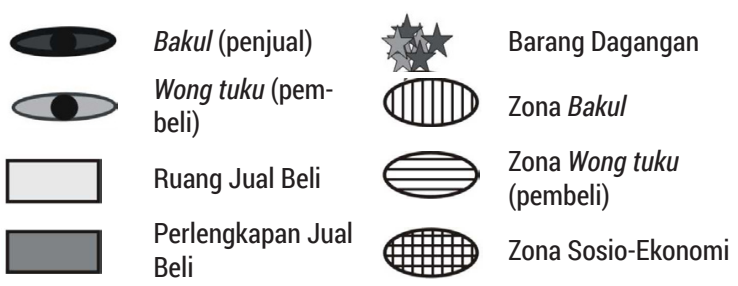

(Sumber: Observasi lapangan, Maret, 2007)

(1)

(2)

Pasar sebagai ruang Interaksi khas antara bakulan mewadahi para pengguna pasar di kegiatan ekonomi. Kabupaten Bantul salah Dalam hal ini, setidaknya satunya merefleksikan terdiri atas dua (2) pasar sebagai ruang pengguna ruang yaitu sosial sekaligus ruang bakul (membangun area bakulan. Dalam hal ini, bakul) dan wong tuku pasar selain mewadahi (membangun area wong kegiatan ekonomi juga tuku) mewadahi kegiatan sosial.

Selain bakulan, di pasar juga berkembang berbagai kegiatan lain, seperti arisan dan simpan pinjam. Kegiatan tersebut ada yang dikelola oleh orang lokal/setempat dan ada pula yang dikelola oleh orang dari wilayah lain. Arisan berkembang dengan baik di pasar-pasar karena pengikutnya cukup banyak. Para bakul menyukai kegiatan ini karena bagi mereka arisan sama halnya dengan menabung. Peserta arisan menyetorkan sejumlah uang setiap waktu sesuai periode yang disepakati dan kemudian memperoleh uang dalam jumlah tertentu pada saat menang 
undian. Kegiatan menabung ini cukup praktis bagi para bakul karena mereka tidak perlu pergi ke bank. Pengelola arisan yang mendatangi mereka di ruang bakulan-nya setiap waktu tertentu untuk mengumpulkan uang arisan. Saat pengundian sangat mereka nantikan karena adanya pengharapan untuk menang. Saat pengundian digunakan oleh para peserta arisan sebagai sarana untuk berkumpul, saling bertemu dan bertegur sapa.

Interaksi sosial yang terjadi pada saat pengundian arisan merupakan salah satu peristiwa rutin yang selalu ditunggu para bakul. Tidak jarang mereka menghabiskan waktu cukup lama pada kumpulan ini, meskipun acara pengundian arisan sudah selesai dilakukan. Para bakul menikmati saat-saat berkumpul dan bercengkerama antara satu dengan lainnya, karena pada kesempatan ini mereka bisa saling bertukar informasi dan cerita. Selain arisan, kegiatan simpan pinjam dan perkreditan juga berkembang di pasar.

Dorongan untuk berada di pasar berkembang di kalangan para pengguna pasar. Meskipun kegiatan bakulan sudah dan barang dagangannya sudah habis, banyak bakul yang tidak segera pulang dan menyempatkan berkumpul dan berbincang dengan pengguna pasar yang lain, seolah ada keengganan dari para bakul dan wong tuku untuk meninggalkan pasar cepat-cepat. Kesempatan berharga ini menjadi sarana untuk menjalin rasa persaudaraan dan mendekatkan diri satu dengan lainnya sehingga memberikan rasa tenang pada diri. Banyak pengguna pasar yang datang sekedar untuk berjalan-jalan melihat keramaian pasar. Selain itu, bagi masyarakat pasar, siklus pekenan adalah siklus pertemuan sosial untuk menyambungkan perkenalan dan persaudaraan masyarakat satu wilayah dengan wilayah lainnya.

Suasana kekeluargaan sangat kental terasa saat berbaur dengan masyarakat pasar. Terasa kepedulian dan keakraban yang khas dalam berbagai kegiatan di pasar. Persaudaraan yang kental antara pengguna pasar satu dan lainnya

mewarnai interaksi yang terjadi. Perluasan hubungan persaudaraan merupakan salah satu keuntungan nonmaterial yang dapat diperoleh sambil melakukan kegiatan ekonomi. Semakin eratnya hubungan sosial lama dan terbangunnya hubungan sosial baru sangat diharapkan dapat terjadi. Menurut para bakul, persaudaraan adalah kekayaan yang usianya lebih panjang dan kemanfaatannya lebih besar dibandingkan dengan kekayaan material. Kentalnya nilai sosial dalam kegiatan masyarakat pasar di Kabupaten Bantul berdampak pada pengatur ulangan kontrol ruang oleh para pengguna pasar. Dasar pemikiran ini diimplementasikan dengan membuka dan melonggarkan batas-batas kontrol ruang oleh para pengguna ruang bakulan sehingga terbentuk setting spesifik di pasar-pasar di Kabupaten Bantul seperti ditunjukkan dalam Gambar 5.

\section{Gambar 5}

Perluasan Interaksi Sosial Masyarakat Pasar

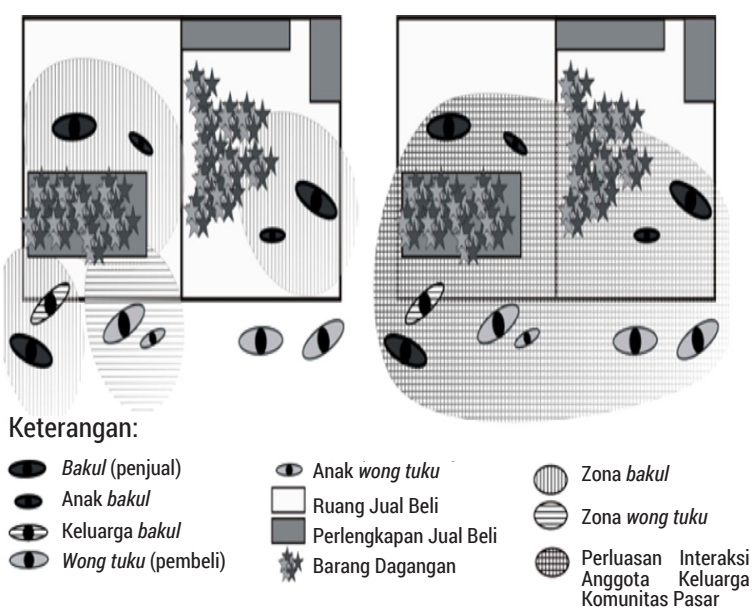

(Sumber: Observasi lapangan, Maret, 2012)

(1)

$\begin{array}{lrlr}\text { Dalam masyarakat } & \text { Interaksi } & \text { antar-individu } \\ \text { pasar } & \text { terbentuk } & \text { anggotar komunitas } \\ \text { interaksi } & \text { antar individu } & \text { meluas menjadi interaksi } \\ \text { anggota } \quad \text { komunitas } & \text { antar keluarga dari individu } \\ \text { tersebut. } & & \text { anggota komunitas pasar. }\end{array}$

Berdasarkan observasi mendalam dapat
diidentifikasikan hal-hal mendasar yang
mempengaruhi pengendalian ruang pasar, yaitu
upaya masyarakat pasar untuk saling mendekatkan
diri antara satu dengan lainnya dengan cara 
membangun persaudaraan-persaudaraan baru, mengembangkan persaudaraan-persaudaraan lama, dan berupaya mencegah kemungkinankemungkinan terjadinya konflik di antara mereka, dengan tujuan untuk mendapatkan rasa aman dan nyaman berada di antara saudara.

Para pelaku kegiatan di pasar berkegiatan dan berinteraksi satu dengan lainnya, membangun komunitas berupa masyarakat pasar. Dalam hubungan kemasyarakatan di pasar, interaksi antara satu dengan lainnya direalisasikan dalam berbagai kegiatan. Salah satunya adalah kegiatan sosial kemasyarakatan antara anggota satu dengan lainnya, seperti saling membantu, saling mengunjungi, dan saling simpati antara satu dengan lainnya.

Pasar merupakan fasilitas umum yang boleh digunakan oleh siapa saja, dengan mengikuti aturan/kesepakatan bersama yang diadakan untuk menghindari terjadinya konflik. Ruang di pasar tidak tercipta secara tiba-tiba atau atau secara serentak. Ruang di pasar secara terus-menerus mengalami perubahan yang diakibatkan oleh dinamika kegiatan dan tuntutan para pengguna serta intervensi kepentingan berbagai pihak. Pemanfaatan pasar di lokasi studi terbentuk melalui proses konsolidasi antara para penggunanya dan masyarakat secara umum. Dengan demikian, tatanan fisik ruang sangat terkait dengan aktivitas yang dilakukan di dalamnya, serta budaya masyarakat.

Berbagai kegiatan yang terjadi di pasar di antaranya adalah kegiatan bakulan, ibadah, beristirahat, mengasuh anak, arisan, simpan pinjam, interaksi sosial, membangun persaudaraan, bertukar informasi, bertukar pengetahuan, dan bertukar budaya. Terjadinya berbagai kegiatan di pasar mengakibatkan timbulnya tatanan ruang yang beragam. Beberapa interaksi dan kegiatan terjadi secara bersamaan dalam ruang bakulan, menuntut pengendalian ruang secara spesifik. Kedekatan dan keakraban antara para pengguna pasar merupakan pemandangan yang biasa di pasar, bahkan di antara mereka yang baru saja saling mengenal. Menurut para bakul, sikap kerukunan ini didasari oleh keinginan mereka untuk selalu membangun hubungan baik antara sesama manusia. Harmonisasi hubungan diupayakan dengan sedapat mungkin menghindari terjadinya konflik dan mengembangkan persaudaraan. Hal ini didasari oleh pemahaman bahwa persaudaraan akan memperpanjang umur. Persaudaraan merupakan kekayaan nyata saat manusia masih hidup dan bahkan setelah meninggal. Berbagai kegiatan yang terjadi di pasar membangun suasana khas pasar di Kabupaten Bantul. Kompleksitas kegiatan ini mengandung muatan ekonomi, sosial, dan budaya para penggunanya yang terwujud dalam perilaku.

Relasi yang terbentuk di pasar tidak saja terbatas pada relasi ekonomi, tetapi sarat dengan nilai sosial. Pelaku kegiatan bakulan di pasar mencakup bakul, wong tuku, pengelola, pemasok barang, dan masyarakat umum. Relasi-relasi yang terbentuk di ruang ini melibatkan seluruh pelaku dan terjadi baik dalam kelompok maupun dalam kelompok besar. Salah satu relasi yang berkembang adalah yang bersifat kekeluargaan. Selain interaksi keluarga asli yang dilakukan di pasar oleh para penggunanya, interaksi "keluarga baru" juga berkembang di pasar. Para pengguna pasar saling menganggap keluarga antara satu dengan lainnya. Kedekatan interaksi antara para pengguna pasar yang dilakukan dengan mengutamakan paseduluran mampu membangun paseduluran baru dalam masyarakat pasar.

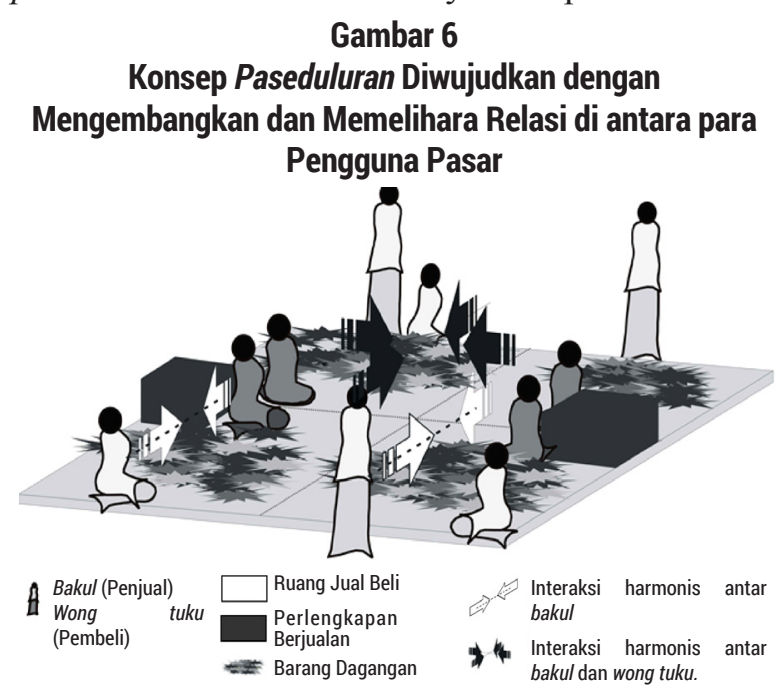

(Sumber: Observasi lapangan, Desember 2012) 
Berkegiatan di pasar bukan lagi ditujukan sekedar pada pemenuhan material, namun lebih dominan diarahkan untuk membangun dan memelihara paseduluran dalam kehidupan bermasyarakat. Motivasi masyarakat pasar untuk selalu mengembangkan dan memelihara paseduluran ini diwujudkan dalam berbagai strategi untuk meminimalkan kemungkinan terjadinya konflik antara masyarakat pasar.

Ruang bakulan komunal berkembang tanpa menggunakan pembatas vertikal antara satu ruang dengan ruang lainnya dalam upaya saling mendekatkan antara para pengguna ruang untuk mendukung berkembangnya relasi sosial di antara mereka. Konsep paseduluran direalisasikan secara fisik dengan minimnya batas antara area bakul dengan area wong tuku sehingga memungkinkan berkembangnya interaksi yang lebih intensif antara bakul dan wong tuku, seperti ditunjukkan dalam Gambar 6 dan 7. Implementasi konsep paseduluran oleh masyarakat pasar membimbing mereka untuk saling mempererat interaksi dan persaudaraan yang sebelumnya telah terjalin, juga membangun relasi dan persaudaraan baru.

\section{Gambar 7}

Tatanan Fisik yang Terbuka pada Ruang Bakulan Mendukung Berkembangnya Paseduluran di Pasar

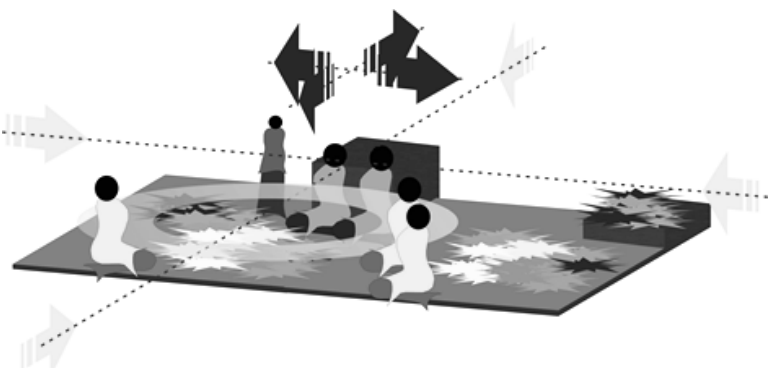

(Sumber: Observasi lapangan, Desember 2012)

Ruang bakulan ditata berupa ruang komunal (los) memberikan peluang seluas-luasnya untuk mewujudkan konsep paseduluran antara para pengguna pasar merupakan realisasi peranan pasar sebagai ruang paseduluran.

\section{SIMPULAN}

Di Kabupaten Bantul, pasar sebagai ruang yang mewadahi kegiatan bakulan masyarakat, ternyata juga dikendalikan untuk mengakomodasi berbagai kegiatan lain yang lebih kompleks. Interaksi antara ruang dan berbagai kegiatan di pasar membentuk tatanan kegiatan dalam pasar. Tatanan ini mencakup tiga komponen, yaitu manusia, kegiatan, dan tata nilai budaya yang dimiliki oleh manusia itu. Cakupan ini mengakibatkan pasar sebagai ruang bakulan mengandung makna dan nilai yang ditanggapi oleh para penggunanya secara khas. Oleh karenanya, observasi terhadap pasar dalam salah satu aspek memungkinkan untuk memunculkan pemaknaan pengguna terhadap ruang dalam kaitannya dengan aspek norma, budaya, dan psikologis masyarakat.

Studi ini menghasilkan simpulan bahwa ada beberapa persepsi pengguna terhadap ruang pasar di Kabupaten Bantul, yaitu (1) pasar sebagai ruang umum; (2) pasar sebagai ruang dhasaran; (3) pasar sebagai ruang kekeluargaan; (4) pasar sebagai media perluasan sosial; (5) pasar sebagai ruang sosioekonomi; (6) pasar sebagai ruang paseduluran; (7) pasar sebagai ruang perbincangan dan ruang hiburan; (8) perubahan pengelolaan ruang pasar, 9) keterbukaan ruang pasar; dan (10) pasar sebagai jaringan informasi, pengetahuan, dan budaya.

Berbagai pemahaman tersebut menunjukkan peranan pasar, yaitu (1) pasar sebagai wadah pengontrol fisik-pengembangan ruang pasar menyesuaikan dengan tuntutan perilaku pengguna, (2) pasar sebagai wadah fungsi komersialpengembangan ruang pasar dilengkapi dengan sarana pendukung kegiatan ekonomi, (3) pasar sebagai lingkungan sosial-pengembangan ruang pasar mengakomodasi tuntutan kegiatan sosial masyarakat, dan (4) pasar sebagai realisasi budaya-ruang pasar saat ini merupakan realisasi perkembangan budaya masyarakat sejak lampau. 
Berbagai persepsi pengguna dan peran pasar di Kabupaten Bantul menunjukkan realisasi pasar yang dominan sebagai lingkungan sosial implementasi budaya masyarakat. Dari berbagai pemahaman masyarakat terhadap pasar, ditemukan bahwa nilai budaya yang dominan mempengaruhi perkembangan ruangnya adalah nilai paseduluran.

\section{DAFTAR RUJUKAN}

Altman, Irwin (1975). The Environment and Social Behavior: Privacy, Personal Space, Territory, and Crowding. California: Monterey, Brooks/Cole.

Goffman, E. (1963). Behavior in Public Place. New York: The Free Press.

Habraken. (1998). The Structure of the Ordinary: Form and Control in The Built Environment. USA: Graphic Composition Inc.

Haryadi, Setiawan, B. (1995). Arsitektur Lingkungan dan Perilaku. Yogyakarta: Departemen Pendidikan dan Kebudayaan.

Hediger, H.P. (1950). Wild Animals in Captivity. London: Butterworth and Co.
Lawson, Bryan. (2001). The Language of Space. London: Architectural Press.

Levebvre, Henri. (1991). The Production of Space. UK: English translation edition. Blackwell Publishers. Oxford.

Marlina, Endy. (2011). Ekspresi Budaya Membangun pada Masyarakat Jeron Beteng, Kecamatan Kraton, Yogyakarta. Jurnal Humaniora, 23, 150-165.

(2014). Spatial Control of Post-earthquake Market Based on Paseduluran. Computational Science and Its Applications-ICCSA 2014. Lecture Notes in Computer Science Volume 8582, 2014.

Moundon, Anne Vernez (ed). (1987). Public Street for Public Use. New York: Van Nostrand Reinhold Company.

Muhajir, Noeng. (1993). Metodologi Studi Kualitatif. Jakarta: Rake Sarasin.

Schulz, Christian-Norberg. (1977). The Intention in Architecture. New York: Rizolli.

Sommer, R. (1966). Man's Proximate Environment. Journal of Social Issues. 